\title{
SUPPLEMENTATION OF CONCENTRATE WITH DIFFERENT LEVELS OF PROTEIN ON NUTRIENT INTAKE, DIGESTIBILITY AND GROWTH OF RED CHITTAGONG HEIFERS
}

\author{
S. Barua ${ }^{1}$, M. J. Khan ${ }^{2}$, A. K. F. H. Bhuiyan ${ }^{3}$, M. N. Islam ${ }^{4}$ and S. S. Islam ${ }^{2}$
}

\begin{abstract}
The study was undertaken to investigate the effects of concentrate supplementation with different protein levels on intake, digestibility and growth performance of Red Chittagong (RC) heifers fed urea molasses straw (UMS) based diet. Twelve RC heifers having average live weight of $124.83 \pm 43.15 \mathrm{~kg}$ and aged between 8 to 14 months were selected for 90 days feeding trial. Animals were divided into four groups having three animals in each and were randomly assigned to four dietary treatments in a Randomized Block Design (RBD). The experimental diets were formulated using urea molasses straw (UMS), German grass (Echinochloa grousgalli) with or without concentrate mix (having different levels of protein). All the animals received UMS ad libitum and German grass at the rate of $20 \%$ of total DM intake. In addition to UMS and German grass of control diet $T_{0}$, animals on diets $T_{1}, T_{2}$ and $T_{3}$ were supplied with concentrate mixture at the rate of $10 \%$ of DM intake containing 15,20 and $25 \% \mathrm{CP}$, respectively. Average daily DM intake was $2.65,3.06,2.62$ and $2.86 \mathrm{~kg} / 100 \mathrm{~kg} \mathrm{LW}$ for diets $\mathrm{T}_{0}, \mathrm{~T}_{1}, \mathrm{~T}_{2}$ and $\mathrm{T}_{3}$, respectively and the difference was non significant $(\mathrm{P}>0.05)$. The digestibility of DM, CP, EE, NFE and digestible nutrients (DCP, DEE and DNFE) for diets $\mathrm{T}_{1}$, $\mathrm{T}_{2}$ and $\mathrm{T}_{3}$ was significantly higher than those for diet $\mathrm{T}_{0}$. The daily average liveweight gain of RC heifers fed diets $T_{0}, T_{1}, T_{2}$ and $T_{3}$ were $100,275,333$ and 291 g respectively $(P<0.01)$. Concentrate mixture having $20 \%$ crude protein may be supplemented at the rate of $10 \%$ of DM intake per day for optimum growth of Red Chittagong heifers.
\end{abstract}

Key words : Red Chittagong, Urea molasses straw (UMS), Concentrate, Growth

\section{Introduction}

The majority of the cattle population of Bangladesh is indigenous type. Indigenous cattle possess unique feature system of adaptability not only to the climatic condition but also to the traditional husbandry on poor quality feeds and breed and have better resistance capabilities to withstand environmental stress and tropical diseases (Wahed, 1971). But the productivity of our indigenous cattle has been at jeopardy for long. Red Chittagong Cattle (RCC) is one of the very few potential types of indigenous milk producing cattle of Bangladesh and it is quite suitable for small holder farmers due to its small size and low feed requirements. This animal is available in the eastern part of the country, where they are traditionally fed on rice straw and sometimes grazing on fallow land and

\footnotetext{
${ }^{1}$ Assistant Quality Controller, CP Feed Mill, CP Bangladesh Co Ltd., Savar, Dhaka, Bangladesh

${ }^{2}$ Department of Animal Nutrition, Bangladesh Agricultural University, Mymensingh-2202, Bangladesh

${ }^{3}$ Department of Animal Breeding and Genetics, Bangladesh Agricultural University, Mymensingh-2202, Bangladesh

${ }^{4}$ Department of Dairy Science, Bangladesh Agricultural University, Mymensingh-2202, Bangladesh
}

Received : May 29, 2008) 
Bang. J. Anim. Sci. 2008, 37 (1)

roads sides (Hossain et al., 2006). This system of feeding can hardly satisfy the maintenance need of the animals. Providing supplements with relatively high protein concentrations to ruminants consuming low-quality roughage has been shown to enhance roughage utilization and livestock performance (Gilbery et al., 2006). DelCurto et al. (1990) demonstrated that feeding cattle a supplement containing at least $22 \%$ crude protein increased both intake and utilization of low-quality forage. To optimize productivity it is necessary to provide the animals with quality feeds to meet nutrients requirement. The protein level in the ration is important for growth of the animal at a desired rate. Therefore, the present study was undertaken to investigate the effect of supplementation of concentrate feed with different protein levels on nutrient digestibility and growth of Red Chittagong heifers fed urea molasses straw based diet.

\section{Materials and Methods}

Twelve Red Chittagong heifers weighing, on average, $124.83 \pm 43.15 \mathrm{~kg}$ and aged between 8 to 14 months were selected for the feeding trial. The animals were weighed initially and blocked into three groups according to live weight. The animals in each block were then assigned at random to four dietary treatments designated as $T_{0}, T_{1}, T_{2}$ and $T_{3}$ in a Randomized Block Design (RBD), having three animals in each. Four diets were formulated using urea-molasses-straw (UMS), German grass (Echinochloa grousgalli) and concentrate mixture at different proportions. The control diet $\left(\mathrm{T}_{0}\right)$ consisted of only roughage (UMS + German grass). In addition to UMS and German grass of $\mathrm{T}_{0}$, diets $\mathrm{T}_{1}, \mathrm{~T}_{2}$ and $\mathrm{T}_{3}$ were supplemented with three iso-energetic (10 ME/kg DM) concentrate mixtures at the rate of $10 \%$ of DM containing 15, 20 and $25 \% \mathrm{CP}$. All the diets were fortified with dicalcium phosphate and common salt. Ingredients and nutritive values of concentrate mixtures are shown in Table 1. Fresh and clean drinking water was supplied ad libitum to all the animals.

Table 1. Ingredients and nutritive values of concentrate mixtures

\begin{tabular}{|l|c|c|c|}
\hline \multirow{2}{*}{\multicolumn{1}{|c|}{ Ingredients }} & \multicolumn{3}{c|}{ Concentrate mixtures (kg/100 kg DM) } \\
\cline { 2 - 4 } & $\mathbf{T}_{\mathbf{1}}$ & $\mathbf{T}_{\mathbf{2}}$ & $\mathbf{T}_{\mathbf{3}}$ \\
\hline Wheat bran & 26.05 & 21.70 & 34.73 \\
Rice polish & 22.97 & 22.42 & 21.52 \\
Cracked maize & 32.00 & 21.62 & 0.00 \\
Mustard oil cake & 11.49 & 13.25 & 4.86 \\
Soybean meal & 3.49 & 17.03 & 34.94 \\
Dicalcium phosphate & 2.00 & 2.00 & 2.00 \\
Common salt & 2.00 & 2.00 & 2.00 \\
\hline Nutrient composition (g/kg DM) & & & \\
Crude protein (CP) & 150.03 & 200.02 & 250.03 \\
Metabolizable energy (ME) & 10.51 & 10.49 & 10.50 \\
\hline
\end{tabular}

${ }^{*}$ Calculated according to Menke et al., 1979

The animals were weighed fortnightly to observe live weight change. Representative samples of feed, left over and faeces were subjected to chemical analysis for determination of crude protein, crude fibre, ether extract, ash and nitrogen free extract following the methods of AOAC (1990). A conventional digestion trial was conducted for a period of 10 days towards the end of feeding trial. The amount of feed supplied to each animal during 24 hours was recorded. Representative feed and 
refusal samples were collected daily and stored in polythene bags for proximate analysis. The total quantity of feces voided daily was recorded against each animal and $10 \%$ of well mixed feces was collected every day, sun dried and stored in polythene bags. At the end of collection period, the sun dried feces were mixed together and ground to pass through $20 \mathrm{~mm}$ screen sieve for chemical analysis. Energy values of whole diet were estimated from digestible organic matter (' $D$ ' value) as $\mathrm{ME}(\mathrm{MJ} / \mathrm{kg} \mathrm{DM})=0.16 \times{ }^{\prime} \mathrm{D}$ ' value (MAFF, 1984). The data were analyzed using MSTAT statistical program to compute analysis of variance (ANOVA) for a Randomized Block Design (RBD). Least Significant Difference (LSD) test was also done to compare the treatment means for different parameters (Steel and Torrie, 1980).

\section{Results and Discussion}

\section{Feed and nutrient intake}

The average feed and nutrient intakes of RC cattle fed different diets are shown in Table 2. It is evident from the table that the lowest $\mathrm{DM}$ intake was observed in animals fed diet $\mathrm{T}_{0}$ and the highest value was recorded for diet $\mathrm{T}_{1}(\mathrm{P}<0.05)$. These results are in agreement with the reports of Umunna et al. (1980) who reported dry matter intake increase at higher protein level. Previous researchers reported that dry matter intake increased if protein levels are increased upto optimum levels (30\%) for maximum gains (Beaty et al., 1994).

Table 2. Feed and nutrient intake of heifers fed different diets

\begin{tabular}{|c|c|c|c|c|c|c|}
\hline \multirow{2}{*}{ Parameters } & \multicolumn{4}{|c|}{ Dietary treatments } & \multirow{2}{*}{ LSD } & \multirow{2}{*}{$\begin{array}{c}\text { Level of } \\
\text { significance }\end{array}$} \\
\hline & $\mathbf{T}_{\mathbf{0}}$ & $\mathbf{T}_{1}$ & $\mathbf{T}_{2}$ & $\mathbf{T}_{3}$ & & \\
\hline UMS intake (kg DM/d) & 2.49 & 2.87 & 2.42 & 2.61 & 0.58 & NS \\
\hline Grass intake (kg DM/d) & 0.81 & 0.85 & 0.84 & 0.83 & 0.11 & NS \\
\hline Concentrate intake (kg DM/d) & - & 0.39 & 0.40 & 0.39 & 0.11 & NS \\
\hline Concentrate intake (kg DM/100kg LW) & - & 0.28 & 0.28 & 0.28 & 0.00 & NS \\
\hline Total DM intake (kg/d) & $3.30^{\mathrm{b}}$ & $4.11^{\mathrm{a}}$ & $3.66^{\mathrm{ab}}$ & $3.83^{\mathrm{ab}}$ & 0.56 & $*$ \\
\hline Total DM intake (kg/100kg LW) & 2.65 & 3.06 & 2.62 & 2.86 & 0.71 & NS \\
\hline Total DM intake $\left(\mathrm{g} / \mathrm{kg}^{0.75} / \mathrm{d}\right)$ & 87.85 & 103.55 & 89.86 & 96.49 & 20.84 & NS \\
\hline Estimated ME intake (MJ/d) & $21.51^{b}$ & $28.25^{\mathrm{a}}$ & $25.44^{\mathrm{a}}$ & $26.52^{\mathrm{a}}$ & 3.68 & $*$ \\
\hline Crude Protein intake (g/d) & $259^{\mathrm{b}}$ & $349.30^{\mathrm{a}}$ & $334.30^{\mathrm{a}}$ & $366.70^{\mathrm{a}}$ & 54.82 & $*$ \\
\hline
\end{tabular}

NS Non significant, * Significant at 0.05 level of probability

${ }^{\mathrm{ab}}$ Means values having different superscripts in a row differed significantly $(\mathrm{P}<0.05)$

Animals receiving concentrate having different levels of protein with urea-molasses-straw (UMS) and green grass (diets $\mathrm{T}_{1}, \mathrm{~T}_{2}$ and $\mathrm{T}_{3}$ ), consumed significantly $(\mathrm{P}<0.01)$ higher amounts of $\mathrm{DM}$ than those receiving UMS and green grass only $\left(\mathrm{T}_{0}\right)$. However, when the total DM intake of the animals of different groups were expressed as $\mathrm{kg}$ per $100 \mathrm{~kg}$ live weight or expressed as metabolic body size $\left(\mathrm{g} / \mathrm{kg} \mathrm{w}^{0.75} / \mathrm{d}\right)$, no significant differences were observed. It is evident from the intake data of the present experiment that supplementation of protein with UMS + green grass based diet did not depress the intake of rice straw or total dietary intake rather it stimulated the total feed intake. Similar to the findings of the present experiment, Chowdhury (2001) stated that increase in cotton seed cake (CSC) 
Bang. J. Anim. Sci. 2008, 37 (1)

with UMS, total DM intake increased by $1 \mathrm{~g} / \mathrm{kg} \mathrm{w}^{0.75} / \mathrm{d}$. In another study, Chowdhury (1999) also reported that increase of mustard oil cake (MOC) intake, total DM intake increased by $0.8 \mathrm{~g}$ daily.

The supplemented diets $T_{1}, T_{2}$ and $T_{3}$ received higher amount of protein $(15,20$ and $25 \%$, respectively) from concentrates compare to $\mathrm{T}_{0}$. As a results, crude protein intake by the animals received different diets increased significantly $(\mathrm{P}<0.05)$ with increasing levels of protein in the supplements (Table 2). Increased CP intake with increasing CP levels in supplements in the present study corresponds well with other findings (Gilbery et al., 2006). Average daily ME intake was significantly $(\mathrm{P}<0.05)$ higher in animals fed diet $\mathrm{T}_{2}, \mathrm{~T}_{1}$ and $\mathrm{T}_{3}$ compared to $\mathrm{T}_{0}$ which is consistent with the findings of Yasmin (2006). The results indicated that average daily intakes of DM, CP and ME were higher in animals received different supplemented diets compared with those given unsupplemented diets.

\section{Apparent digestibility and nutritive value}

The effect of protein supplementation on apparent digestibility of proximate components of different diets is shown in Table 3 . The dry matter digestibility of diets $T_{1}, T_{2}$ and $T_{3}$ were significantly $(\mathrm{P}<0.01)$ higher than that of diet $\mathrm{T}_{0}$. However, no significant differences were recorded among the treatments $T_{1}, T_{2}$ and $T_{3}$. From the table it is evident that the digestibility of $D M$ increased significantly $(\mathrm{P}<0.05)$ up to certain level with the increased level of protein content of the diet. Beaty et al. (1994) found that the digestibility of dry matter increased by increasing crude protein content of supplement. Greathouse et al. (1974) reported significantly lower digestibility of DM due to lower amounts of protein in Hereford steers, which are in well agreement with the present findings. However, Chowdhury (1999) stated that digestibility of DM, OM and ADF of straw based diet was not affected by the levels of supplementation of mustard oil cake. The digestibility of CP was significantly $(\mathrm{P}<0.01)$ higher for diets $\mathrm{T}_{1}, \mathrm{~T}_{2}$ and $\mathrm{T}_{3}$ compared to that for control diet, $\mathrm{T}_{0}$. However, the digestibility of $\mathrm{CP}$ for diet $\mathrm{T}_{2}$ was not-significant $(\mathrm{P}>0.05)$ than $\mathrm{T}_{3}$. In fact, $\mathrm{CP}$ digestibility improved linearly with the increase of protein supplementation in the UMS based diet. Greathouse et al. (1974); Umunna et al. (1980) observed gradual increase in protein digestibility with increased protein levels. Chowdhury (1999) stated that increasing levels of mustard oil cake in diet CP digestibility increased. There was no significant $(\mathrm{P}>0.05)$ difference among the dietary treatments for digestibility of $\mathrm{OM}$ and $\mathrm{CF}$ with increased levels of protein supplementation.

Digestible crude protein contents $(\mathrm{g} / 100 \mathrm{~g} \mathrm{DM})$ of different diets varied significantly $(\mathrm{P}<0.05)$ between treatments and values were ranged between 4.05 in $T_{0}$ and 6.64 in $T_{3}$. Digestible crude fibre contents of different diets did not show any significant variation between treatments. However, digestible ether extract and digestible nitrogen free extract contents varied significantly between treatments. Highest TDN value was observed in $\mathrm{T}_{2}$ and lowest in $\mathrm{T}_{0}(\mathrm{P}<0.05)$. ' $\mathrm{D}$ ' value and estimated ME contents of different diets showed significant variations between treatments being highest in $T_{2}$ and lowest in $\mathrm{T}_{0}$.

\section{Live weight gain}

Live weight gain on diets $\mathrm{T}_{3}, \mathrm{~T}_{2}$ and $\mathrm{T}_{1}$ were significantly $(\mathrm{P}<0.01)$ higher than those on diet $\mathrm{T}_{0}$ (Table 4). However, heifers on diets $T_{1}$ and $T_{2}$ or on diets $T_{2}$ and $T_{3}$ did not show any significant $(\mathrm{P}>0.05)$ difference although there was a linear increase of live weight gain with the feeding of increased levels of protein. Banerjee (1998) reported that urea treated diet could support higher weight gain of $300 \mathrm{~g} /$ day in crossbred heifers with supplementation of small quantity of concentrate. Dolberg and Finlayson (1995) by feeding urea treated straw supplemented with cottonseed cake ranging from 0 
up to $4 \mathrm{~kg} / \mathrm{head} / \mathrm{d}$. recorded a curvilinear growth response ranging from 236 to $861 \mathrm{~g} / \mathrm{d}$. Similarly, other related work have reported that supplementation of 0.26 to $0.32 \mathrm{~kg}$ protein /day (Putram et al., 1969 ) and $0.28 \mathrm{~kg}$ protein/day (Greathouse et al., 1974) improved live weight gain.

Table 3. Apparent digestibility and nutritive value of different diets

\begin{tabular}{|c|c|c|c|c|c|c|}
\hline \multirow{2}{*}{ Parameters } & \multicolumn{4}{|c|}{ Dietary treatments } & \multirow{2}{*}{ LSD } & \multirow{2}{*}{$\begin{array}{c}\text { Level of } \\
\text { significance }\end{array}$} \\
\hline & $\mathbf{T}_{\mathbf{0}}$ & $\mathbf{T}_{1}$ & $\mathbf{T}_{\mathbf{2}}$ & $\mathbf{T}_{3}$ & & \\
\hline \multicolumn{7}{|l|}{ Apparent digestibility (g/100 g) } \\
\hline Dry matter (DM) & $49.95^{\mathrm{b}}$ & $54.45^{\mathrm{a}}$ & $58.27^{\mathrm{a}}$ & $56.32^{\mathrm{a}}$ & 4.43 & $*$ \\
\hline Organic matter $(\mathrm{OM}$ & 51.30 & 52.49 & 55.97 & 55.02 & 4.45 & NS \\
\hline Crude protein $(\mathrm{CP})$ & $45.62^{\mathrm{c}}$ & $55.89^{\mathrm{b}}$ & $62.46^{\mathrm{a}}$ & $62.29^{\mathrm{a}}$ & 5.80 & $* *$ \\
\hline Crude fiber (CF) & 63.93 & 66.80 & 69.47 & 66.99 & 4.95 & NS \\
\hline Ether extract (EE & $44.94^{\mathrm{b}}$ & $63.84^{\mathrm{a}}$ & $63.60^{\mathrm{a}}$ & $63.71^{\mathrm{a}}$ & 6.40 & $* *$ \\
\hline Nitrogen free extract (NFE) & $43.47^{\mathrm{b}}$ & $51.34^{\mathrm{a}}$ & $55.51^{\mathrm{a}}$ & $54.83^{\mathrm{a}}$ & 4.69 & $*$ \\
\hline \multicolumn{7}{|l|}{ Nutritive value (g/100 g DM) } \\
\hline Digestible crude protein (DCP) & $4.05^{\mathrm{b}}$ & $4.81^{\mathrm{b}}$ & $6.18^{\mathrm{a}}$ & $6.64^{\mathrm{a}}$ & 1.01 & $*$ \\
\hline Digestible crude fibre (DCF) & 22.56 & 21.95 & 22.61 & 21.88 & 1.51 & NS \\
\hline Digestible ether extract (DEE) & $1.12^{\mathrm{b}}$ & $1.80^{\mathrm{a}}$ & $1.85^{\mathrm{a}}$ & $1.80^{\mathrm{a}}$ & 0.22 & $* *$ \\
\hline Digestible nitrogen free extract (DNFE) & $18.03^{\mathrm{c}}$ & $22.31^{\mathrm{a}}$ & $24.02^{\mathrm{a}}$ & $23.23^{\mathrm{a}}$ & 2.06 & $* *$ \\
\hline Total digestible nutrient (TDN) & $47.17^{\mathrm{c}}$ & $53.13^{\mathrm{b}}$ & $56.98^{\mathrm{a}}$ & $55.80^{\mathrm{ab}}$ & 3.53 & $*$ \\
\hline $\mathrm{D}$ value & $45.77^{\mathrm{c}}$ & $50.88^{\mathrm{b}}$ & $54.67^{\mathrm{a}}$ & $53.55^{\mathrm{ab}}$ & 3.44 & * \\
\hline Estimated ME (MJ/kgDM) & $7.32^{\mathrm{c}}$ & $8.14^{\mathrm{b}}$ & $8.75^{\mathrm{a}}$ & $8.57^{\mathrm{ab}}$ & 0.55 & $*$ \\
\hline
\end{tabular}

NS Non significant, * Significant at 0.05 level of probability, ** Significant at 0.01 level of probability ${ }^{a b c}$ Means values having different superscripts in a row differed significantly $(\mathrm{P}<0.05)$.

Table 4. Growth performance and feed conversion efficiency of heifers fed different diets

\begin{tabular}{|l|c|c|c|c|cc|}
\hline \multirow{2}{*}{\multicolumn{1}{|c|}{ Parameters }} & \multicolumn{4}{c|}{ Dietary treatments } & \multirow{2}{*}{$\begin{array}{c}\text { Level of } \\
\text { significance }\end{array}$} \\
\cline { 2 - 7 } & $\mathbf{T}_{\mathbf{0}}$ & $\mathbf{T}_{\mathbf{1}}$ & $\mathbf{T}_{\mathbf{2}}$ & $\mathbf{T}_{\mathbf{3}}$ & & NS \\
Initial live wt (kg) & 127.17 & 129.00 & 126.33 & 127.50 & 19.26 & $\mathrm{NS}$ \\
Final live wt (kg) & 134.67 & 149.67 & 151.33 & 149.33 & 20.85 & $* *$ \\
Total LWG (kg) & $7.50^{\mathrm{b}}$ & $20.67^{\mathrm{a}}$ & $25.00^{\mathrm{a}}$ & $21.83^{\mathrm{a}}$ & 6.09 & $* *$ \\
Ave. LWG (g/d) & $100.00^{\mathrm{b}}$ & $275.30^{\mathrm{a}}$ & $333.30^{\mathrm{a}}$ & $291.30^{\mathrm{a}}$ & 81.20 & $* *$ \\
Feed conversion efficiency (kg DMI/kg LWG) & $37.40^{\mathrm{a}}$ & $15.62^{\mathrm{b}}$ & $11.04^{\mathrm{b}}$ & $13.14^{\mathrm{b}}$ & 17.65 & $*$ \\
Protein conversion efficiency (CPI /LWG) & $2.94^{\mathrm{a}}$ & $1.33^{\mathrm{b}}$ & $1.01^{\mathrm{b}}$ & $1.25^{\mathrm{b}}$ & 1.44 & $*$ \\
Energetic efficiency (MEI/LWG) & $243.35^{\mathrm{a}}$ & $107.52^{\mathrm{b}}$ & $76.78^{\mathrm{b}}$ & $90.87^{\mathrm{b}}$ & 116.2 & $*$ \\
\hline
\end{tabular}

NS Non significant, * Significant at 0.05 level of probability. ** Significant at 0.01 level of probability

${ }^{\mathrm{ab}}$ Means values having different superscripts in a row differed significantly $(\mathrm{P}<0.05)$

\section{Feed conversion efficiency}

Feed conversion efficiency of animals fed diets containing different levels of protein supplement is shown in Table 4. The results revealed that there were significant $(\mathrm{P}<0.05)$ differences among the 
Bang. J. Anim. Sci. 2008, 37 (1)

diets for converting feed into live might gain. The animals fed on diets $T_{1}, T_{2}$ and $T_{3}$ which had different levels of protein supplement, showed significantly $(\mathrm{P}<0.05)$ higher for feed conversion efficiency than that of the animals fed on diet $\mathrm{T}_{0}$ (without supplement). However, no difference $(\mathrm{P}>0.05)$ was observed for this parameter among the dietary groups $\mathrm{T}_{1}, \mathrm{~T}_{2}$ and $\mathrm{T}_{3}$. Previous works of Umunna et al. (1980) revealed that increase in protein levels after a certain level declined the feed conversion. In contrary, Greathouse et al. (1974) reported higher rate of feed conversion due to rising of protein level. The differences in results of the two authors might have occurred due to the breed difference as Rogerson et al. (1968); Zemmelink et al. (1973) reported that feed conversion ratio was very much related to animal species and breed differences. The results revealed that the protein conversion efficiency differed significantly $(\mathrm{P}<0.05)$ between unsupplemented and supplemented groups and highest value was observed in $\mathrm{T}_{2}$ (Table 4). Energetic efficiency of converting feed energy into live weight gain was significantly better in supplemented groups than unsupplemented group.

\section{Conclusion}

From this experiment it may be concluded that supplementation of concentrate mixture containing different levels of protein improved nutrient digestibility and live weight gain of RC heifers feed UMS based diet. Concluded that concentrate mixture having $20 \%$ crude protein may be supplemented at the rate of 10 percent of DM intake per day to the diets of RC heifers for achieving optimum growth.

\section{Acknowledgements}

The authors are grateful to late Professor Dr. M. Shahjalal, Department of Animal Nutrition, Bangladesh Agricultural University for his valuable contribution in conducting the research. The authors are also acknowledge the financial assistance from USDA under which this work was conducted.

\section{Literature Cited}

AOAC. 1990. Official Methods of Analysis (15 ${ }^{\text {th }}$ ed.). Association of official Analytical Chemist, Arlington, VA. Banerjee, G. C. 1998. A Text Book of Animal Husbandry, $8^{\text {th }}$ ed., Oxford and IBH Pub. Co. Ltd., New Delhi, India.

Beaty, J. L., Cochran, R. C., Lintzenich, B. A., Vanzant, E. S., Morrill, J. L., Jr. Brandt, R.T. and Johnson, D. E. 1994. Effect of frequency of supplementation and protein concentration in supplements on performance and digestion characteristics of beef cattle consuming low-quality forages. J. Anim. Sci. 72 : 2475-2486.

Chowdhury, S. A. 2001. Effect of graded levels of cotton seed cake supplementation on intake, nutrient digestibility, microbial $\mathrm{N}$ yield of growing native (Bos indicas) bull fed rice straw. Asian-Australasian J. Anim. Sci. 14(3) : 326-332.

Chowdhury, S. A. 1999. Effect of graded levels of mustard oil cake supplementation on intake, nutrient digestibility, microbial $\mathrm{N}$ yield of adult cannulated native (Bos indicus) bulls fed rice straw. AsianAustralasian J. Anim. Sci. 12(5) : 715-722.

DelCurto, T., Cochran, R. C., Harman, D. L., Beharka, A. A., Jacques, K. A. Towne, G. and Vanzant, E. S. 1990. Supplementation of dormant tallgrass-prairie forage: 1 . Influence of varying supplemental protein and (or) energy levels on forage utilization characteristics of beef steers in confinement. J. Anim. Sci. 68 : 515-531. 
Dolberg, F. and Finlayson, P. 1995. Treated straw for beef production in China. World Anim. Rev. 82 : 14-24.

Gilbery, T. C., Lardy, G. P., Soto-Navarro, S. A., Bauer, M. L. and Caton, J. S. 2006. Effects of corn condensed distillers solubles supplementation on ruminal fermentation, digestion, and in situ disappearance in steers consuming low-quality hay. J. Anim. Sci. 84 : 1468-1480.

Greathouse, G. A, Schalles, R. R., Brent, B. E., Dayton, A. D. and Smith, E. F. 1974. Effects of levels and sources of protein on performance and carcass characteristics of steers fed all-concentrate rations. J. Anim. Sci. 39 : 102-107.

Hossain, M. M., Bhiuyan, A. K. F. H., Faruque, M. O. and Dev, G. K. 2006. Characterization and distribution pattern of Red Chittagong cattle of Bangladesh. Progressive Agric. 17 (1) : 103-110.

MAFF. 1984. Energy Allowances and Feeding Systems for Ruminants. Reference Book 433. HMSO, London.

Menke, K. H., Raab, L., Salewaski, A., Steingass, H., Fritz, D. and Schnerider, W. 1979. The estimation of digestibility and metabolizable energy content of ruminant feedstuffs from the gas production when they are incubated with rumen liquor in vitro. J. Agric. Sci. $93: 217-222$.

Putram, P. A, Oltjen, R. P. and Bond, J. 1969. Effect of soybean oil, urea, roughage and a progestigia on the utilization of corn based finishing rations by beef cattle. J. Anim. Sci. $28: 256$.

Rogerson, A, Ledger, H. P. and Freeman, G. H. 1968. Food intake and live weight gain comparison of Bos indicus and Bos Taurus steers on high plane of nutrition. Anim. Prod. $10: 373-380$.

Steel, R. G. R. and Torrie, J. H. 1980. Principles and Procedures of Statistics, $2^{\text {nd }}$ edition. Mc Graw-Hill Int. Book Co. New Delhi.

Umunna, N. N, Dakintafo, A. and Carew, S. N. 1980. Influence of levels of dietary protein on performance and carcass characteristics of Zebu steers fed high energy rations. Tropical Anim. Prod. 5 : 161-164.

Wahed, A. B. M. F. 1971. Scope of cattle production in Bangladesh. Bangladesh J. Anim. Sci. 4(1-2) : 1-3.

Yasmin, M. F. 2006. Effect of supplementing concentrate on intake, digestibility, milk yield and composition of Red Chittagong cows fed urea molasses straw based diet. M.S. Thesis. Department of Animal Nutrition, Bangladesh Agricultural University, Mymensingh, Bangladesh.

Zemmelink, G., Leeuw, de and Harbers, L. B. 1973. Effect of plane of nutrition on comparative weight gains of White Fulani and Friesian x White Fulani crossbred bulls. Tropical Anim. Health and Prod. 5 : 57-64. 